\title{
Creative tourism: opportunities for smaller places?
}

\section{Turismo criativo: oportunidade para pequenos locais?}

\author{
Greg Richards \\ Tilburg University, Tilburg School of Social and Behavioral Sciences, Department of Leisure Studies, The Netherlands, \\ G.W.Richards@uvt.nl
}

\begin{abstract}
This paper aims to review the development of creativity in tourism, and analyses the potential role of smaller places in creative development. In the past, the role of creativity has been primarily analysed in larger cities. In recent years, more attention has been paid to the creative development of smaller cities and regions. We argue that smaller places should not attempt to emulate big city models of creative development, such as attracting the creative class, but should find their own creative mode based on using their endogenous resources, capacity building and bottom-up creativity. In this way they can avoid the 'creativity trap' of following generic creativity models and develop modes of creative tourism more appropriate to their size and capabilities.
\end{abstract}

Keywords: Creative tourism, creativity, creative industries, small cities, rural areas.

\section{Resumo}

Este artigo tem como objetivo revisar o desenvolvimento da criatividade no turismo e analisa o papel potencial de pequenos locais no desenvolvimento criativo. No passado, o papel da criatividade foi analisado principalmente nas grandes cidades. Nos últimos anos, mais atenção tem sido dada ao desenvolvimento criativo de cidades e regiões menores. Argumentamos que locais de menor dimensão não devem tentar imitar modelos de desenvolvimento criativo de grandes cidades, como atrair a classe criativa, mas devem encontrar seu próprio modo criativo baseado no uso de seus recursos endógenos, capacitação e criatividade da base para o topo. Desta forma, é possível evitar a "armadilha da criatividade" de seguir modelos genéricos de criatividade e desenvolver modos de turismo criativo mais apropriados ao seu tamanho e capacidades.

Palavras-chave: Turismo criativo, criatividade, indústrias criativas, pequenas cidades, áreas rurais.

\section{Introduction}

The need for places to distinguish themselves in a globalising world has increased attention for the challenges facing smaller communities. How can places that lack large populations or significant clusters of resources compete effectively against 'world cities' and other larger places that dominate the global economy? A range of recent analyses has begun to shed light on the potential of small cities and rural communities to make use of knowledge, relationships and creative resources to position themselves more effectively in global networks and stimulate growth (Brouder, 2012; Bell \& Jayne, 2006; Pierce, Martin \& Murphy, 2011; OECD, 2014).

The debate about the role of smaller places is also now extending to the tourism field. On the one hand, we can see the growing power of a number of major urban centres in the tourism field, driven by the growth of mobility, new forms of accommodation and the seemingly endless desire of consumers for experiences. Cities such as Barcelona, Venice, Lisbon and Amsterdam are now threatened by the spectre of 'overtourism', with increased friction between residents and visitors as a result (Richards, 2017). In contrast, many smaller communities, particularly in rural areas, are struggling to attract enough visitors to create economic and social opportunities for their inhabitants.

Some have argued that one developmental opportunity for small places is the development of creative resources and 'creative tourism' (Richards \& Raymond, 2017). This is also one of the aims of the CREATOUR Project, a Portuguese creative tourism network focusing on small cities and rural areas within the Norte, Centro, Alentejo and Algarve regions. In the view of this network,

Creative tourism experiences combine different creative content elements and engage with creative lifestyles. Visitors or consumers want to be actively involved in creative experiences and activities. Creative tourism consumers desire to "go where the creativity is" and to directly participate in creation and co-creation activities. They are increasingly playing a co-creation role in the development of creative experiences, sharing knowledge, and contributing skills to the creative experiences. Creative tourism experiences are not only economically valuable, but may stimulate the development of new ideas, products, and services through the interactions, conversations, and co-creation experiences that occur. (CREATOUR, 2017).

Arguably, in order to succeed, creative experiences must be embedded in the destination so that "people have a reason to be creative in a particular place. Destinations have to identify characteristic creative content and activities that connect with the needs of visitors and residents" (OECD 2014: 54).

In particular, for smaller places, this means developing creative networks that link together the creative resources of the location, the creative producers and potential consumers. This is precisely what initiatives such as CREATOUR and other projects in Portugal and elsewhere are trying to achieve (e.g. Cunha Lima \& Flores e Silva, 2017). This paper tries to assess the creative potential of smaller places and how creative tourism might play a role in their creative development strategies. 


\section{Growing attention for smaller places}

The development of creative tourism can be seen as part of the broader 'creative turn' in society and the social sciences. The most high-profile examples of this turn have included the creative development strategies of major cities, driven by the ideas of academics and consultants such as Richard Florida and Charles Landry. One of the key ideas underpinning the creative turn in cities is the suggestion that people no longer follow jobs - economic growth follows people, and in particular creative people. The prescription for growth is therefore to attract creative people - the more creatives, the more creative and therefore, attractive the city.

This argument has tended to focus attention on large cities that have concentrations of creative industries and clusters of creative people. Many large cities have therefore developed policies to become 'creative cities', either as a replacement for, or as an adjunct to, culture-led regeneration strategies. These often involve a mix of cultural hardware and creative software, with the development of iconic museums and cultural centres as a common centrepiece. This is perhaps a sensible strategy for major cities with significant cultural, creative and financial resources, but what about smaller places?

Recent years have seen more attention being paid to the creative potential of smaller places. In particular, smaller cities and places offer a higher quality of life, which is attracting a growing number of creatives. Although the creative industries have traditionally been linked with big cities as sites where creative production and face to face contact between creative entrepreneurs are concentrated, these activities are now also becoming more commonplace in smaller cities as well. New technologies are allowing people to locate creative activities to rural areas, and intangible heritage is becoming a more important aspect of tourism experiences (OECD, 2014).

There are also more possibilities for smaller places to compete with big cities through re-sizing strategies. In the past, smaller places have had to resort to 'borrowing size' in physical terms (Alonso, 1973; Meijers \& Burger, 2015), but the advent of the network society means there are new potential strategies for smaller cities to compete effectively. For example, an event can provide a useful framing device for creativity, and also act as a temporal concentrator and temporary re-sizing strategy. The European Capital of Culture in Guimarães (held in 2012), provides an example of creative industries development in a small Portuguese city.

Our research shows that the ECOC in Guimarães (one of the smallest ever ECOC host cities at 60,000 people) was successful in linking the cultural heritage of the city to industrial heritage and the creative industries. The injection of money provided by the ECOC allowed Guimarães to invest in new infrastructure, such as a new concert hall. Most places do not have this option, but even so events can provide a significant catalyst for small places. Our research concluded that "the ECOC in Guimarães has had a bigger proportional effect on the people visiting the city during the event than was the case in Porto in 2001." (Porto was the previous Portuguese ECOC) (Richards 2014).

The city of 's-Hertogenbosch (Den Bosch) in the Netherlands is another example of a small city punching above its weight (Duif, 2016). Although the city has an attractive historic centre, it has struggled for years to develop a distinct image and to inject more creativity into what is essentially a heritage tourism product. The city is the birthplace of the famous medieval painter Hieronymus Bosch, who lived, worked and died there. But the city ignored this important legacy for decades for one simple reason - it had none of Bosch's paintings. These are spread around museums in different countries in Europe and the United States. But one the city made the bold decision to develop a programme of events commemorating the $500^{\text {th }}$ anniversary of Bosch's death in 2016, it became clear that a means would have to be found to lay claim to this artistic heritage (Duif, 2016). The city achieved this by setting up a network of 'Bosch Cities' - all those that had works by the painter. It then established the Bosch Research and Renovation Project, dedicated to analysing and restoring the valuable medieval works using the expert knowledge available in the Netherlands. The city then offered to research and restore the works held by other cities for free. The only catch was that the cities were then asked to send their works to Den Bosch in 2016 for a major exhibition. This strategy was so successful that the city eventually managed to gather 17 of the 25 surviving paintings and almost all of the drawings. The exhibition created such a furore that the available tickets sold out fast, prompting the exhibition hours to be extended until it was open for 39 hours continuously on the last weekend. The exhibition ended up with over 420,000 visitors, taking $10^{\text {th }}$ position in the Art Newspaper review of busiest exhibitions in the world in 2016. This was feat described as a 'miracle' by the Guardian newspaper, and the city is now busy developing the creative leverage of the event by turning itself into a knowledge hub on medieval art. The whole Bosch programme attracted 1.4 million visits in total. This shows that creativity, and effective storytelling can be crucial in attracting people to small places.

Creative tourism can be a particularly useful strategy for small places because it is based on personal interaction, one-to-one contacts between tourists and locals and depth of place experience. In many locations, therefore, rural environments have provided to be successful in developing creative tourism programmes. For example, Blapp (2016) reports on the experiences of villages in Bali that have attracted tourists with creative experiences, and in Thailand, creative tourism is being used as a means of stimulating community-based tourism development (Wisansing, 2015). Many of these programmes are based on aspects of intangible heritage and the daily life of communities in smaller settlements, which can also be a way of conserving and promoting local traditions and ways of life. There are also emerging examples of new models of creative tourism in rural areas, which include the development of knowledge hubs, maker festivals, rural networks and niche specialisation. 
Despite the success of such programmes, smaller communities also need to be aware of the potential pitfalls in developing creative tourism. These include the danger of copying formats from elsewhere, which can lead to a form of 'serial reproduction', as Blapp (2016) notes in the case of Indonesia. This underlines the importance of creatively seeking what is characteristic or special about each location in order to provide engaging and unique experiences.

These challenges are already evident in the early stages of the CREATOUR project. With 20 pilot projects presenting their creative tourism ideas at the launch conference in Curia in June 2017, it is clear that small places have a limited range of resources to draw on, and have the additional challenge of shrinking and ageing populations. This means that many of the projects have similar ideas, such as using gastronomy, ceramics or textiles as a basis for creative tourism. Creativity needs to be engaged to link these basic resources more clearly to specific places in order to underline their authenticity and uniqueness. Local residents often think that what they have is unique, but to the outsider, small places can seem remarkably similar, as Blapp observed.

There is also a need to consider issues of available resources and skills. Very often, smaller places do not possess the knowledge required to develop all aspects of creative programmes successfully. This places stress on the role of networks in connecting smaller places to each other in order to 'create size', and to link them to the source markets from which tourists are drawn. Networks provide the leverage necessary for small places to operate effectively in a globalising world. They can be a means of co-creating and sharing knowledge, which is the basic resource for creative development.

\section{Modes of creativity}

It is increasingly clear that creativity offers many possibilities for small places. But it is not a panacea. The experience of small cities that have tried to emulate the model of larger 'creative cities' has been largely negative (Lewis \& Donald, 2009). The idea of a 'onesize-fits-all' model seems to be particularly inappropriate for small places. Rather than seeing creativity as a model of attracting the creative class or developing a creative city, smaller places should see creativity as a mode of thinking that allows them to maximise their potential.

The difference between 'model' and 'mode' may seem small, but in terms of orientation, process and outcome, they are poles apart. A model is "a standard or example for imitation or comparison", which the serial reproduction of creative city models and the ranking of places according to their degree of creativity or size of their creative class underlines. A mode, on the other hand, can be defined as "a manner of acting or doing; method; a way". Adopting a creative mode, therefore, does not mean copying others, but finding your own way. It implies a unity of thought and action - of creative practice.

The creative practices of small places should be based on the three basic elements of creative development as described by Sacco and Blessi (2007). They argued that the approach to developing a 'creative district' should involve not just increasing attractiveness, but also capacity building and competitiveness. In terms of attractiveness, Sacco and Blessi analyse the important elements of the work of Richard Florida (2002), and argue that attracting and retaining talent is a major challenge for creative places everywhere. Similarly, using Sen's ideas on capacity building, they emphasise the importance of producing knowledge and building the social fabric of places. Borrowing from Porter (1980), they also argue that places need to be competitive.

Building on the work of Sacco and Blessi, Bucci, Sacco \& Segre (2014) propose an endogenous growth model based on investment in culture and human resources. They emphasise that although culture is universal, it is also very local, being based on the 'genus loci' of each place, however small. By investing in cultural capital, arguably even small places can achieve growth. This seems to be supported by data from the Alto Minho, which show that the small town of Vila Nova de Cerveira has managed to reverse population decline by developing an arts festival and supporting its artistic community (Machado et al., 2014).

The important elements of the models of Sacco and Blessi and Bucci et al. include: developing cultural quality, development of local enterprises and talent, attracting firms and talent, reducing marginality, capacity building, participation, education and networking. For small places, in particular, there is a need to combine social dynamism with traditional economic tools. The lack of agglomeration advantages means that small places have to build their economic fabric in other ways, for example, by using social and cultural resources to stimulate growth. This means that they need to be more open and pay more attention to capacity building than big cities might need to do. Because of the heavy reliance of social and cultural processes in small places on grassroots activity, the creative mode adopted needs to be more open and more bottom-up than the prescriptive models put forward by many development experts. Table 1 below indicates some of the ways in which the adoption of a creative mode by places is different from applying creative models.

Table 1 - Creative models vs creative modes

\begin{tabular}{|l|l|l|}
\hline Way of thinking & \multicolumn{1}{|c|}{ Creative Model } & \multicolumn{1}{c|}{ Creative Mode } \\
\hline Way of being & Prescriptive & Open \\
\hline Way of moving & Following & Leading \\
\hline Way of relating & Fast & Slow \\
\hline Way of inspiring & Top-down & Bottom-up \\
\hline Way of competing & Gurus & Everyday creativity \\
\hline & Size & Position \\
\hline
\end{tabular}

Source: own elaboration. 
By adopting creative practices, and thinking holistically about creativity as a mode of being rather than as a sector or a social group, small places have a better chance of creating interesting alternatives to the development models of big cities.

\section{Conclusion}

Creative development and creative tourism seem to offer interesting development opportunities for smaller communities. However, they need to avoid the 'creativity trap' of copying models from bigger places, or assuming that attracting members of the 'creative class' will solve their problems. Rather than trying to emulate bigger places, small cities and rural areas need to develop their own creative modes and practices that are more suited to their scale and pace of life. Creative tourism, in particular, is not a form of mass tourism but can be an individualised, small-scale alternative to the development of mass cultural tourism (Richards, 2016). Attracting small numbers of highly motivated visitors may end up producing far more significant economic, social and cultural effects than trying to attract tourist masses.

\section{Acknowledgement}

An earlier version of this paper was presented at the CREATOUR Conference "The State of the Art in Creative Tourism", Curia, Portugal, June 1st 2017.

\section{References}

Alonso, W. (1973). Urban zero population growth. Daedalus, 109, 191-206. Bell, D. \& Jayne, M. (2006). Small Cities: Urban experience beyond the metropolis. London: Routledge.

Blapp, M. (2015). Creative Tourism in Bali's Rural Communities Examination of the current offer and advice on future product development. MA Dissertation NHTV University of Applied Sciences in Breda, Netherlands, December 2015.

Brouder, P. (2012). Creative outposts: Tourism's place in rural innovation. Tourism Planning \& Development, 9(4), 383-396.

Bucci, A., Sacco, P.-L. \& Segre, G. (2014). Smart endogenous growth: cultural capital and the creative use of skills. International Journal of Manpower, 35(1/2), 33-55.

CREATOUR (2017). The State of the Art in Creative Tourism. Call for Projects, CREATOUR.

Cunha Lima, F. B., \& Flores e Silva, Y. (2017). " Project Querença" and creative tourism: visibility and local development of a village in the rural Algarve. E-review of Tourism Research, 14, 21-35.

Duif, L. (2016). De magie van Bosch: Oude schilders, nieuwe citymarketing. MMNieuws, September.

Lewis, N. M., \& Donald, B. (2009). A New Rubric for 'Creative City' Potential in Canada's Smaller Cities. Urban Studies, 47 (1), 29-54.

Machado, R., Fernandes, C. \& Queiroz, J.P. (2014). Exploring the Biennial concept to promote new relationships in art, culture and alternative tourism. In G. Richards \& P. Russo, (eds), Alternative and Creative Tourism (pp. 70-81), Arnhem: ATLAS.

Meijers, Evert J. \& Burger, Martijn J. (2015). Stretching the concept of 'borrowed size'. Urban Studies, 54(1), 269-291.

OECD (2014). Tourism and the Creative Economy. Paris: OECD.

Pierce, J., Martin, D. G. \& Murphy, J. T. (2011). Relational place-making: the networked politics of place. Transactions of the Institute of British Geographers, 36(1), 54-70.

Richards, G. (2014). Guimarães and Maribor, European Capitals of Culture 2012. Arnhem: ATLAS.
Richards, G. (2016). The challenge of creative tourism. Ethnologies, 38(1-2), 31-45.

Richards, G. (2017). Heritage tourism: benefit or liability for cities? Are cities with a long history now suffering a quick death at the hands of tourism? Cartaditalia: Rivista di cultura italiana contemporanea, 2018, 395-415.

Richards, G. \& Duif, L. (2018). Small Cities with Big Dreams: Creative Placemaking and Branding Strategies. New York: Routledge.

Richards, G. \& Raymond, C. (2000). Creative Tourism. Atlas News, 1(23), 16-20.

Sacco, P. L. \& Blessi, G. (2007). European Culture Capitals and Local Development Strategies: Comparing the Genoa 2004 and Lille. Homo Oeconomicus 24(1), 111-141.

Wisansing, J. (2015). Redesign tourism. Bangkok: DASTA.

Received: 15 June 2018

Revisions required: 25 September 2018

Accepted: 14 December 2018 